\title{
Characterization of a heat-resistant extracellular protease from Pseudomonas fluorescens 07A shows that low temperature treatments are more effective in deactivating its proteolytic activity
}

\author{
Maura P. Alves, ${ }^{\star}$ Rafael L. Salgado,† Monique R. Eller, $\ddagger$ Pedro Marcus P. Vidigal, $\S$ \\ and Antonio Fernandes de Carvalho*1 \\ *Inovaleite Laboratory, Department of Food Technology, \\ †Department of Biochemistry and Molecular Biology, \\ ‡Department of Food Technology, and \\ §Núcleo de Análise de Biomoléculas (NuBioMol), Universidade Federal de Viçosa, Viçosa, Minas Gerais, Brazil, 36570000
}

\begin{abstract}
This work discusses the biological and biochemical characterization of an extracellular protease produced by Pseudomonas fluorescens. The enzyme has a molecular weight of $49.486 \mathrm{kDa}$ and hydrolyzes gelatin, casein, and azocasein, but not BSA. Its maximum activity is found at $37^{\circ} \mathrm{C}$ and $\mathrm{pH} 7.5$, but it retained almost $70 \%$ activity at $\mathrm{pH}$ 10.0. It was shown to be a metalloprotease inhibited by $\mathrm{Cu}^{2+}, \mathrm{Ni}^{2+}, \mathrm{Zn}^{2+}, \mathrm{Hg}^{2+}, \mathrm{Fe}^{2+}$, and $\mathrm{Mg}^{2+}$, but induced by $\mathrm{Mn}^{2+}$. After incubation at $100^{\circ} \mathrm{C}$ for $5 \mathrm{~min}$, the enzyme presented over $40 \%$ activity, but only 14 to $30 \%$ when submitted to milder heat treatments. This behavior may cause significant problems under conditions commonly used for the processing and storage of milk and dairy products, particularly UHT milk. A specific peptide sequenced by mass spectrometer analysis allowed the identification of gene that encodes this extracellular protease in the genome of Pseudomonas fluorescens 07A strain. The enzyme has $477 \mathrm{AA}$ and highly conserved $\mathrm{Ca}^{2+}$ - and $\mathrm{Zn}^{2+}$-binding domains, indicating that $\mathrm{Ca}^{2+}$, the main ion in milk, is also a cofactor. This work contributes to the understanding of the biochemical aspects of enzyme activity and associates them with its sequence and structure. These findings are essential for the full understanding and control of these enzymes and the technological problems they cause in the dairy industry.
\end{abstract}

Key words: milk proteolysis, protease, enzyme characterization, heat treatment

\section{INTRODUCTION}

The storage of raw milk under refrigeration conditions contributes to improved milk quality. However, a

Received March 29, 2016.

Accepted May 11, 2016.

${ }^{1}$ Corresponding author: antoniofernandes@ufv.br long-term storage allows the development of psychrotrophic bacteria (Sørhaug and Stepaniak, 1997), and predominantly the genera Pseudomonas (Ercolini et al., 2009; Decimo et al., 2014; von Neubeck et al., 2015). The majority of these microorganisms produce thermoresistant proteases, which maintain activity even after milk pasteurization or UHT treatment (McPhee and Griffiths, 2011). Residual activity of these enzymes on casein micelles can cause technological problems and is associated with loss of yield in cheese production, formation of off-flavor in dairy products, UHT milk gelation, and coagulation of milk proteins during storage (Datta and Deeth, 2001; McPhee and Griffiths, 2011).

Several studies partially characterized proteases from psychrotrophic bacteria isolated from milk (Liao and McCallus, 1998; Dufour et al., 2008; Zhang and Lv, 2014). However, to fully understand protease activity in milk, it is essential to associate this characteristic with others such as their biochemical properties, complete sequence, and structure. These data will assist dairy industries in the development or adaptation of alternatives to control technological problems in dairy products.

Pseudomonas fluorescens 07A, a proteolytic strain, was isolated from raw bulk milk (Pinto, 2004; Martins et al., 2005) and produces an extracellular protease responsible for milk deterioration, even at low temperatures. However, little information is known about this enzyme, the conditions in which it is produced, and its activity in milk. Thus, this work describes the biological and biochemical properties of the extracellular protease produced by $P$. fluorescens $07 \mathrm{~A}$ and identifies its coding sequence in the genome of this bacterium.

\section{MATERIALS AND METHODS}

\section{Bacteria and Culture Conditions}

The strain P. fluorescens 07A was isolated from raw milk collected in Minas Gerais, Brazil (Pinto, 2004; 
Martins et al., 2005). The culture was cultivated in Luria-Bertani broth (Sigma-Aldrich, St. Louis, MO) at $25^{\circ} \mathrm{C}$.

\section{Proteolysis Assay}

The proteolytic activity was determined using azocasein (Sigma-Aldrich) as substrate, as described by Ayora and Götz (1994), with modifications. An aliquot of $250 \mu \mathrm{L}$ of azocasein solution at $2 \%$ (mass/vol) in diluted in $40 \mathrm{~m} M$ Tris- $\mathrm{HCl}, 2 \mathrm{mM} \mathrm{CaCl}{ }_{2}$ buffer, $\mathrm{pH}$ 7.5 , was added to $150 \mu \mathrm{L}$ of the test solution. The mixture was agitated, incubated at $37^{\circ} \mathrm{C}$ for $8 \mathrm{~h}$, and the reaction was interrupted with $1.2 \mathrm{~mL}$ of trichloroacetic acid at $10 \%$ (mass/vol). After incubation for $15 \mathrm{~min}$ at room temperature, the mixture was centrifuged at $12,000 \times g$ for $15 \mathrm{~min}$ at $4^{\circ} \mathrm{C}$. A volume of $1.2 \mathrm{~mL}$ of the supernatant was neutralized with $1.0 \mathrm{~mL}$ of $1 \mathrm{M} \mathrm{NaOH}$. The absorbance of this solution was measured at 440 nm using a SpectraMax M2 spectrometer (Molecular Devices, Sunnyvale, CA). One unit of enzymatic activity was defined as the quantity of enzyme sufficient to raise 0.01 of the solution absorbance at $440 \mathrm{~nm}$ per minute, at experimental conditions. All assays were performed as triplicates and the results were expressed as the mean \pm standard deviation.

The protein concentration was estimated as Bradford (1976) using BSA (Sigma-Aldrich) to build the calibration curve.

\section{Protease Purification}

A solution containing the bacteria $P$. fluorescens $07 \mathrm{~A}$ in exponential phase was inoculated $(1 \%)$ in Luria-Bertani, incubated for $18 \mathrm{~h}$, and centrifuged at 10,000 $\times g$ for $15 \mathrm{~min}$ at $4^{\circ} \mathrm{C}$. The enzyme was recuperated from crude supernatant by fractional precipitation using ammonium sulfate (40 to $60 \%$ ) for $1 \mathrm{~h}$ and centrifugation at $12,000 \times g$ for $30 \mathrm{~min}$ at $4^{\circ} \mathrm{C}$. Pellet was resuspended in $10 \mathrm{~m} M$ Tris- $\mathrm{HCl}, 50 \mathrm{~m} M \mathrm{NaCl}$ buffer, $\mathrm{pH} 7.5$, and dialyzed twice against this buffer in cellulose membrane of $14 \mathrm{kDa}$ (Sigma-Aldrich), for $8 \mathrm{~h}$. All steps were performed at $4^{\circ} \mathrm{C}$, and an aliquot was collected to monitor the enzyme activity.

Dialyzed solution containing the enzyme was applied in a HiPrep 26/60 Sephacryl S-200 HR column (GE Healthcare, Little Chalfont, UK) equilibrated with 10 $\mathrm{m} M$ Tris- $\mathrm{HCl}, 50 \mathrm{~m} M \mathrm{NaCl}$ buffer, $\mathrm{pH} 7.5$, using an AKTA Purifier chromatographer (GE Healthcare). Proteins were recuperated at $1.6 \mathrm{~mL} / \mathrm{min}$ and monitored at $280 \mathrm{~nm}$. Fractions presenting proteolytic activity were subjected to ultrafiltration in Amicon Ultra-15 (Millipore, Cork, Ireland) and storage at $4^{\circ} \mathrm{C}$.
The aliquots collected from each purification step were subjected to a SDS-PAGE with $12 \%$ polyacrylamide (Laemmli, 1970) in a Mini-Protean Tetra System (Bio-Rad, Hercules, CA). Proteins were stained with silver nitrate or $0.01 \%$ Coomassie Brilliant Blue R-250 solution.

The same aliquots were subjected to a zymogram using a $12 \%$ polyacrylamide gel and gelatin $(3 \mathrm{mg} / \mathrm{mL})$ as substrate, as described by Feitosa et al. (1998), with modifications. Gels were washed during $30 \mathrm{~min}$ with a Triton X-100 2.5\% (vol/vol) solution and incubated in $50 \mathrm{~m} M$ Tris- $\mathrm{HCl}, 200 \mathrm{mM} \mathrm{NaCl}, 5 \mathrm{mM} \mathrm{CaCl} 2$ buffer, $\mathrm{pH} 7.5$, at $37^{\circ} \mathrm{C}$ for $12 \mathrm{~h}$. Proteolytic activity was visualized as clear zones in the gel stained with a $0.01 \%$ Coomassie Brilliant Blue R-250 solution.

Beyond gelatin, proteolytic activity was tested in zymograms using casein, azocasein, and BSA as substrates.

\section{Protease Characterization}

Effect of Temperature and $p H$ on Enzyme Activity. Proteolysis assay was performed with incubation temperatures of $4,10,20,30,50$, and $60^{\circ} \mathrm{C}$. Enzyme activity was also evaluated at the $\mathrm{pH}$ range of 4.0 to 10.0. Enzyme solutions were adapted to each $\mathrm{pH}$ of the test using $1 M$ buffers with $50 \mathrm{mM} \mathrm{NaCl}$ and 2 $\mathrm{m} M \mathrm{CaCl}_{2}$. A sodium citrate/citric acid buffer was used for $\mathrm{pH} 4.0$ and 5.0; a sodium phosphate buffer was used for $\mathrm{pH} 6.0$ and Tris- $\mathrm{HCl}$ for $\mathrm{pH} 7.5,8.0,9.0$, and 10.0. A negative control with no enzyme was performed for all solutions. Results were expressed as relative units, considering maximum activity as $100 \%$.

Effect of Inhibitors and Metallic Ions on Enzyme Activity. The activity assay was performed with the addition of the following reagents: EDTA ( 1 and $5 \mathrm{mM}$ ), 1,10-phenantroline (1 and $5 \mathrm{mM}$ ), PMSF (1 and $5 \mathrm{mM}$ ), benzamidine $(1$ and $5 \mathrm{mM}$ ), dithiothreitol (DTT; 1 and $5 \mathrm{mM})$, E-64 (1, 5, and $10 \mu M)$, and Pepstatin A (1, 5, and $10 \mu M$; Sigma-Aldrich). The ions tested were $\mathrm{Mg}^{2+}, \mathrm{Cu}^{2+}, \mathrm{Zn}^{2+}, \mathrm{Ca}^{2+}, \mathrm{Fe}^{2+}, \mathrm{Mn}^{2+}, \mathrm{Ni}^{2+}$, and $\mathrm{Hg}^{2+}$ at concentrations of 2 and $5 \mathrm{mM}$. A negative control with no enzyme was performed for all solutions. Results were expressed as relative units, considering the solution with no inhibitors and ions as $100 \%$.

Enzyme Thermostability. Aliquots of $150 \mu \mathrm{L}$ of the protease solution were incubated in microtubes at $80^{\circ} \mathrm{C}$ during $5,10,15$, and $20 \mathrm{~min}$ and at 90 and $100^{\circ} \mathrm{C}$ during 1,3 , and $5 \mathrm{~min}$. The protease was also incubated at $72^{\circ} \mathrm{C}$ for $15 \mathrm{~s}$ and $65^{\circ} \mathrm{C}$ for 30 min to test the heat treatments of rapid and slow pasteurization, respectively, commonly applied to milk. The aliquots were immediately cooled in ice bath and subjected to 
the proteolysis assay. Results were expressed as relative units, considering the non-heat-treated solution as $100 \%$. The effect of the ion $\mathrm{Mn}^{2+}(5 \mathrm{mM})$ on enzyme thermostability was also evaluated at $80^{\circ} \mathrm{C}$ for 5,10 , 15 , and $20 \mathrm{~min}$.

\section{Protease Sequencing Using MALDI TOF/TOF}

Tryptic digestion of protease was based in the work of Wiśniewski et al. (2009), with modifications. One milliliter of a solution with $90 \mu \mathrm{g}$ of the enzyme was filtered using $0.5 \mathrm{~mL}$ of Amicon Ultra, with cut off molar mass of $10 \mathrm{kDa}$ (Millipore). The retained material was resuspended in $50 \mathrm{~m} M$ ammonium bicarbonate (AMBIC), agitated for $60 \mathrm{~s}$, added with $10 \mathrm{~m} M \mathrm{DTT}$, and incubated for $60 \mathrm{~min}$ at room temperature. The material was acetylated with $10 \mathrm{~m} M$ iodoacetamide and incubated for $60 \mathrm{~min}$ at room temperature, protected from light. The solution was centrifuged at 10,000 $\times g$ for $20 \mathrm{~min}$ at $4^{\circ} \mathrm{C}$ and the retained material was washed twice with a $50 \mathrm{~m} M$ AMBIC and $0.5 M$ urea solution, followed by centrifugation at $10,000 \times g$ for $20 \mathrm{~min}$ at $4^{\circ} \mathrm{C}$. The material was then washed twice with a AMBIC $50 \mathrm{mM}$ and centrifuged at 10,000 $\times g$ for $20 \mathrm{~min}$ at $4^{\circ} \mathrm{C}$. A trypsin solution was added to the retained material (Sigma-Aldrich), at a final concentration of $25 \mathrm{ng} / \mu \mathrm{L}$, and the mixture was incubated at $37^{\circ} \mathrm{C}, 400$ $\mathrm{rpm}$, for $20 \mathrm{~h}$. The solution containing the peptides was centrifuged at $10,000 \times g$ for $20 \mathrm{~min}$ at $4^{\circ} \mathrm{C}$ and the filtrate was transferred to a new tube. Peptides were concentrated at a vacuum concentrator (Eppendorf, Hauppauge, NY) for approximately $12 \mathrm{~h}$ and subjected to a matrix-assisted laser desorption/ionization tandem time-of-flight (MALDI TOF/TOF) analysis (Supplemental Material; http://dx.doi.org/10.3168/ jds.2016-11236).

The mass/charge ratios of the theoretical tryptic peptides of proteins were analyzed using Mascot Server 2.4 (Matrix Science, London, UK), Scaffold Q+ 3.0 Software (Proteome Software, Portland, OR), and Peaks Online Server 7 (Bioinformatics Solutions Waterloo, ON, Canada; Supplemental Material S1; http:// dx.doi.org/10.3168/jds.2016-11236) and predicted by the peptidemass tool from Expasy (http://web.expasy. org/peptide_mass). They were manually compared with the lists of masses generated by the MS1 analysis from MALDI TOF/TOF (Altuntas et al., 2014).

\section{Identification of the Gene Encoding the Extracellular Protease on the P. fluorescens 07A Genome}

The genome of the strain P. fluorescens 07A was partially sequenced in a previous study that isolated the UFV-P2 phage from this bacteria (Eller et al., 2014).
The sequenced reads that assembled the UFV-P2 genome were excluded from the data set and the remaining 45 million of paired reads with 51 nucleotides were selected for the $P$. fluorescens $07 \mathrm{~A}$ genome. These reads were assembled in contigs using CLC Genomics Workbench version 6.5.1 (CLC bio, Aarhus, Denmark), producing 603 sequences with an average size of $9.9 \mathrm{~kb}$. Contigs sequences were analyzed using Prodigal software (http://prodigal.ornl.gov/). A total of 5,446 genes were identified and the encoded proteins were functionally annotated using Basic Local Alignment Search Tool (BLAST) searches against reference proteomes of $P$. fluorescens available at UniProt (http://www.uniprot. org/). This protein data set was selected as reference on peptide sequencing. The sequenced peptides were submitted to BLAST searches against contigs of the P. fluorescens 07A genome and the predicted proteins.

\section{RESULTS}

\section{Protease Purification}

The enzyme was partially purified from the $P$. fluorescens $07 \mathrm{~A}$ supernatant. The fractions of 0 to $40 \%$ and 40 to $60 \%$ of ammonium sulfate presented proteolytic activity by the zymogram and proteolysis assay. The fraction 40 to $60 \%$ was chosen for the next steps because it contained less contaminant proteins (Figure 1 , line 2). This fraction was purified with a Sephacryl S-200 HR column and 3 peaks could be observed, one of which presented proteolytic activity. Fractions corresponding to this peak were concentrated with Amicon Ultra-15 and subjected to electrophoresis. The apparent molecular weight for this protease is $50 \mathrm{kDa}$ (Figure 1, line 3). Beyond gelatin, the protease hydrolyzed casein and azocasein, but not BSA.

\section{Effect of Temperature and pH on Enzyme Activity}

Protease activity was maintained in a wide range of conditions of 4 to $60^{\circ} \mathrm{C}$ (Figure 2a) and $\mathrm{pH}$ of 5.0 to 10.0 (Figure $2 \mathrm{~b}$ ). The enzyme presented maximum activity at $37^{\circ} \mathrm{C}$ and $\mathrm{pH} 7.5$. Over $95 \%$ activity was maintained at $50^{\circ} \mathrm{C}$, but above this temperature, enzyme activity was considerably reduced (Figure 2a). In pH 6.0, 90\% of the maximum proteolytic activity was observed. This value is slightly below the $\mathrm{pH}$ of milk. In $\mathrm{pH} 8.0$, the activity was reduced to $68 \%$ of the optimum and remained practically constant until $\mathrm{pH} 10.0$ (Figure $2 \mathrm{~b}$ ).

\section{Effect of Inhibitors and Metallic lons on Enzyme Activity}

Inhibitors of aspartyl protease (pepstatin A) and serine protease (PMSF and benzamidine) had no effect on 


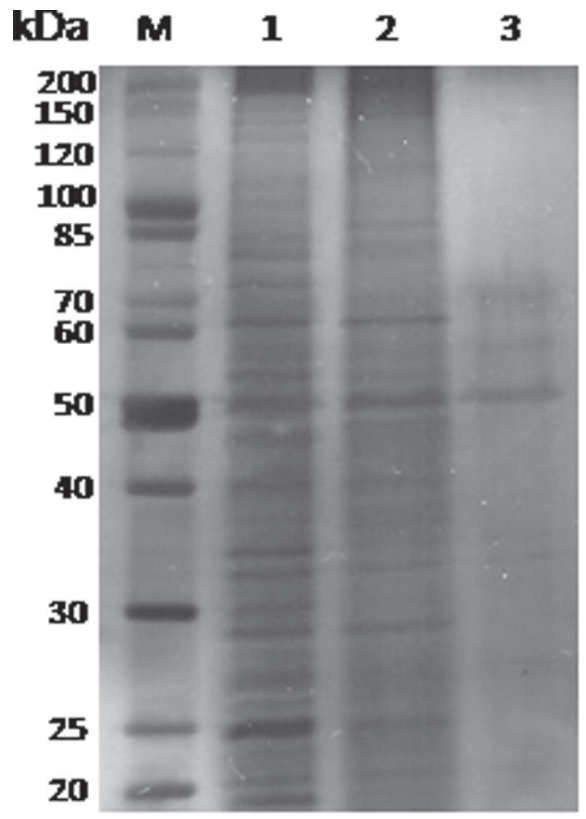

(A)

Figure 1. Sodium dodecyl sulfate-PAGE (A) and zymogram (B) of the proteolytic fractions in the purification steps. Lane M: molecular marker; lane 1: Pseudomonas fluorescens 07A crude extract; lane 2: fraction 40 to $60 \%$ of ammonium sulfate; lane 3: partially purified protease after chromatography.

protease activity (Table 1), indicating that this enzyme does not belong to these catalytic groups. On the other hand, $5 \mathrm{~m} M$ of EDTA, an agent chelant of divalent ions, and 1,10-phenantroline, chelant of $\mathrm{Zn}^{2+}$, have reduced

Table 1. Effect of inhibitors on protease activity ${ }^{1}$

\begin{tabular}{llr}
\hline Inhibitor & $\begin{array}{c}\text { Concentration } \\
(\mathrm{m} M)\end{array}$ & $\begin{array}{c}\text { Relative activity } \\
(\%)\end{array}$ \\
\hline Control & 0 & $100.0 \pm 1.39$ \\
Pepstatin A & 0.001 & $98.5 \pm 1.93$ \\
& 0.005 & $97.1 \pm 1.83$ \\
E-64 & 0.01 & $97.6 \pm 1.10$ \\
& 0.001 & $90.7 \pm 3.42$ \\
EDTA & 0.005 & $88.5 \pm 3.13$ \\
& 0.01 & $80.4 \pm 0.28$ \\
PMSF & 1 & $91.3 \pm 1.71$ \\
& 5 & $13.4 \pm 2.34$ \\
1,10-Phenanthroline & 1 & $92.2 \pm 2.00$ \\
Benzamidine & 5 & $100.8 \pm 0.11$ \\
& 1 & $44.8 \pm 1.71$ \\
DTT & 5 & $2.6 \pm 0.28$ \\
& 1 & $94.0 \pm 0.21$ \\
& 5 & $97.8 \pm 1.92$ \\
& 1 & $57.3 \pm 1.60$ \\
& 5 & $47.7 \pm 0.32$ \\
\hline
\end{tabular}

${ }^{1}$ Relative activity is the percentage of activity in the control treatment (without inhibitors). E-64 = trans-epoxysuccinyl-L-leucylamido(4-guanidino) butane, PMSF = phenylmethylsulfonyl fluoride, DTT $=$ dithiothreitol. Values of relative activity are expressed as mean of triplicate $\pm \mathrm{SD}$. enzyme activity in 87 and $97 \%$, respectively. Protease activity was also reduced in the presence of DTT.

The ion $\mathrm{Ca}^{2+}$ had no effect on protease activity, different from ions $\mathrm{Cu}^{2+}, \mathrm{Ni}^{2+}, \mathrm{Zn}^{2+}, \mathrm{Hg}^{2+}, \mathrm{Fe}^{2+}$, and $\mathrm{Mg}^{2+}$, which had decreasing levels of inhibition, respectively, at $2 \mathrm{mM}$ (Table 2). Moreover, protease activity was stimulated in the presence of $\mathrm{Mn}^{2+}$, with an increase of 67.6 and $87.8 \%$ at manganese concentrations of 2 and $5 \mathrm{~m} M$, respectively.

a

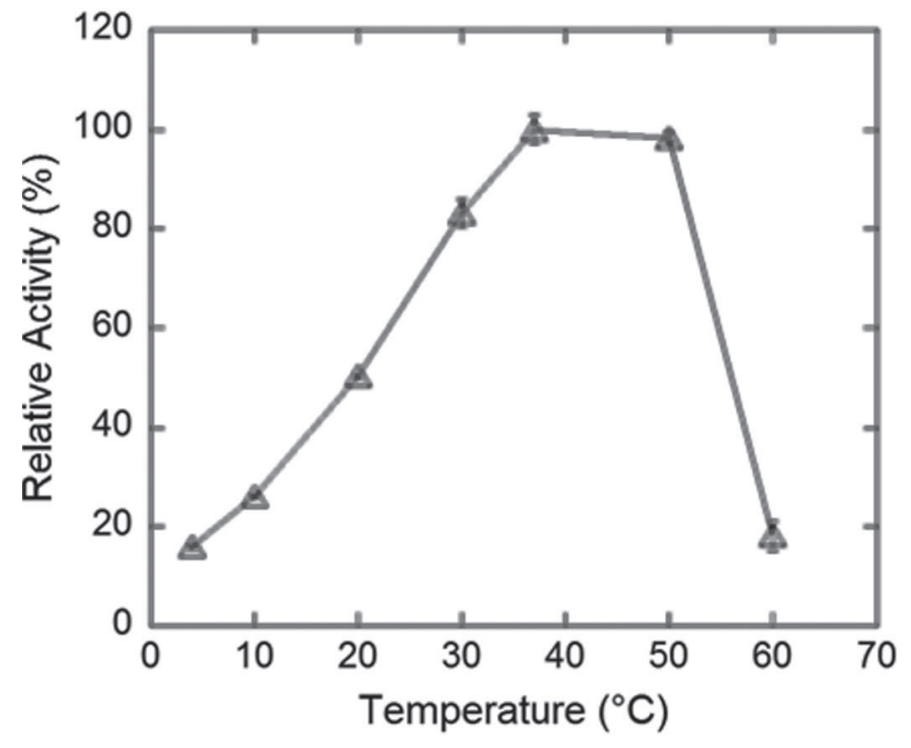

b

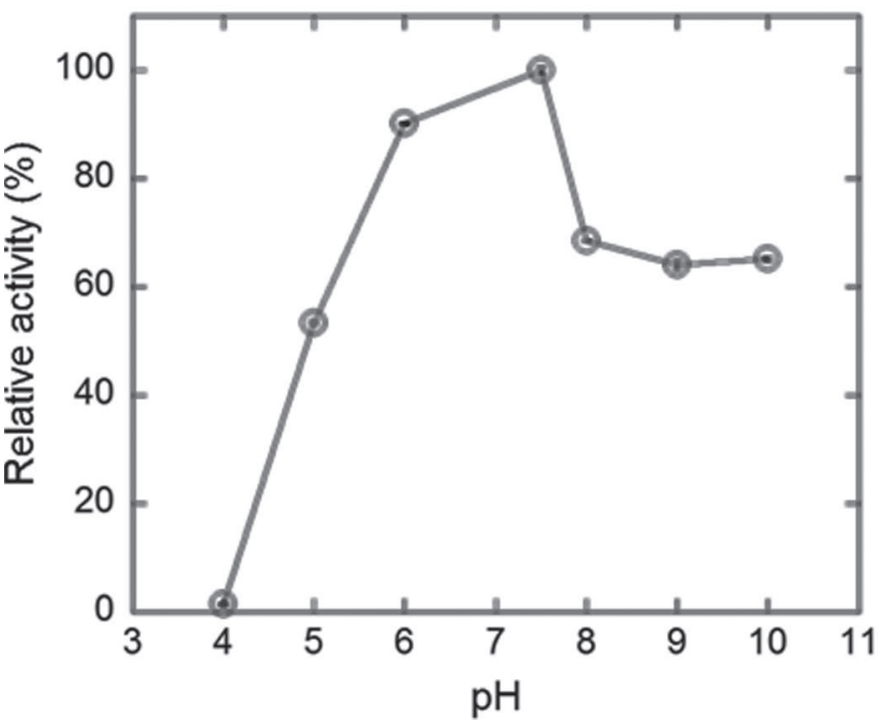

Figure 2. Effect of temperature (a) and $\mathrm{pH}$ (b) on the activity of the extracellular protease from Pseudomonas fluorescens 07A. Error bar represents the mean of triplicate \pm SD. 
Table 2. Effect of metallic ions on protease activity ${ }^{1}$

\begin{tabular}{lrr}
\hline & \multicolumn{2}{c}{ Concentration $(\mathrm{m} M)$} \\
\cline { 2 - 3 } Ion & \multicolumn{1}{c}{2} & \multicolumn{1}{c}{5} \\
\hline $\mathrm{Mg}^{2+}$ & $92.4 \pm 0.09$ & $90.4 \pm 0.18$ \\
$\mathrm{Cu}^{2+}$ & $39.7 \pm 0.18$ & $11.7 \pm 0.46$ \\
$\mathrm{Zn}^{2+}$ & $72.3 \pm 0.09$ & $33.4 \pm 0.83$ \\
$\mathrm{Ca}^{2+}$ & $99.1 \pm 2.57$ & $100.2 \pm 3.21$ \\
$\mathrm{Ni}^{2+}$ & $56.2 \pm 0.09$ & $54.2 \pm 0.55$ \\
$\mathrm{Mn}^{2+}$ & $167.6 \pm 1.10$ & $187.8 \pm 3.67$ \\
$\mathrm{Hg}^{2+}$ & $77.0 \pm 0.09$ & $51.2 \pm 2.02$ \\
$\mathrm{Fe}^{2+}$ & $78.0 \pm 2.11$ & $75.3 \pm 1.30$ \\
\hline
\end{tabular}

${ }^{1}$ Relative activity is the percentage of activity compared with a control treatment with no ions $(100.00 \pm 2.30 \%)$. Values of relative activity are expressed as mean of triplicate $\pm \mathrm{SD}$.

\section{Protease Thermostability}

The enzyme presented $31.7 \%$ of residual activity when subjected to the temperature of $72^{\circ} \mathrm{C}$ for $15 \mathrm{~s}$ (HTST) and $14.3 \%$ when incubated at $65^{\circ} \mathrm{C}$ for $30 \mathrm{~min}$ (low temperature and long time; LTLT), conditions similar to the heat treatments of milk pasteurization (Table 3). Moreover, the protease retained 44, 44, and $40 \%$ of its initial activity, even after the treatments of 80,90 , and $100^{\circ} \mathrm{C}$ respectively, for $5 \mathrm{~min}$.

Because the protease activity was stimulated in the presence of $\mathrm{Mn}^{2+}$, the thermostability of this enzyme was also assessed in the presence and absence of $\mathrm{MnCl}_{2}$ at $80^{\circ} \mathrm{C}$. The presence of this ion had a positive effect on residual enzyme activity, but not in enzyme thermostability, because the rate of decrease of enzyme activity due to the heat treatment was greater in the presence of this ion (Figure 3).

\section{Identification of the Gene Encoding the Extracellular Protease on the Bacteria P. fluorescens 07A Genome}

Tryptic peptides obtained from protease digestion were submitted to a MALDI TOF/TOF analysis and a peptide sequence could be associated with a specific protein encoded by a gene predicted in the $P$. fluorescens 07A genome (Figure 4). The contig sequence containing the extracellular protease has $14.63 \mathrm{~kb}$ and was sequenced with an average coverage of 400fold (GenBank accession number KU170026). This contig contains 13 genes and the extracellular protease is encoded by gene g5. This sequence has 1,434 bp and encodes a protein with $477 \mathrm{AA}$, which was functionally annotated as extracellular metalloprotease (Supplemental Table S1; http://dx.doi.org/10.3168/ jds.2016-11236). This protein has a predicted mass of 49,486 Da and an isoelectric point of 5.06. Similarity searches showed that this protein is highly conserved among P. fluorescens strains (Supplemental Table S1
Table 3. Thermostability of the extracellular protease from Pseudomonas fluorescens $07 \mathrm{~A}^{1}$

\begin{tabular}{lcc}
\hline $\begin{array}{l}\text { Temperature } \\
\left({ }^{\circ} \mathrm{C}\right)\end{array}$ & $\begin{array}{c}\text { Time } \\
(\mathrm{min})\end{array}$ & $\begin{array}{c}\text { Relative activity } \\
(\%)\end{array}$ \\
\hline Control & 0 & $100.0 \pm 0.00$ \\
65 & 30 & $14.3 \pm 0.37$ \\
72 & 0.25 & $31.7 \pm 0.37$ \\
80 & 5 & $44.1 \pm 1.10$ \\
& 10 & $32.6 \pm 0.08$ \\
& 15 & $33.0 \pm 0.44$ \\
90 & 20 & $21.3 \pm 1.24$ \\
& 1 & $55.5 \pm 1.66$ \\
& 3 & $44.7 \pm 0.83$ \\
100 & 5 & $43.6 \pm 0.58$ \\
& 1 & $60.1 \pm 0.10$ \\
& 3 & $43.9 \pm 0.84$ \\
\end{tabular}

${ }^{1}$ Values of relative activity are expressed as mean of triplicate \pm SD.

and Figure S1; http://dx.doi.org/10.3168/jds.201611236). However, the sequence alignment showed that the extracellular protease of $P$. fluorescens 07A strain has few polymorphisms that differentiate this protein from other proteins identified in P. fluorescens strains (Supplemental Figure S1).

\section{DISCUSSION}

The presence of proteases produced by psychrotrophic microorganisms in milk results in degradation of casein micelles and hence in many technological problems in dairy industries (McPhee and Griffiths,

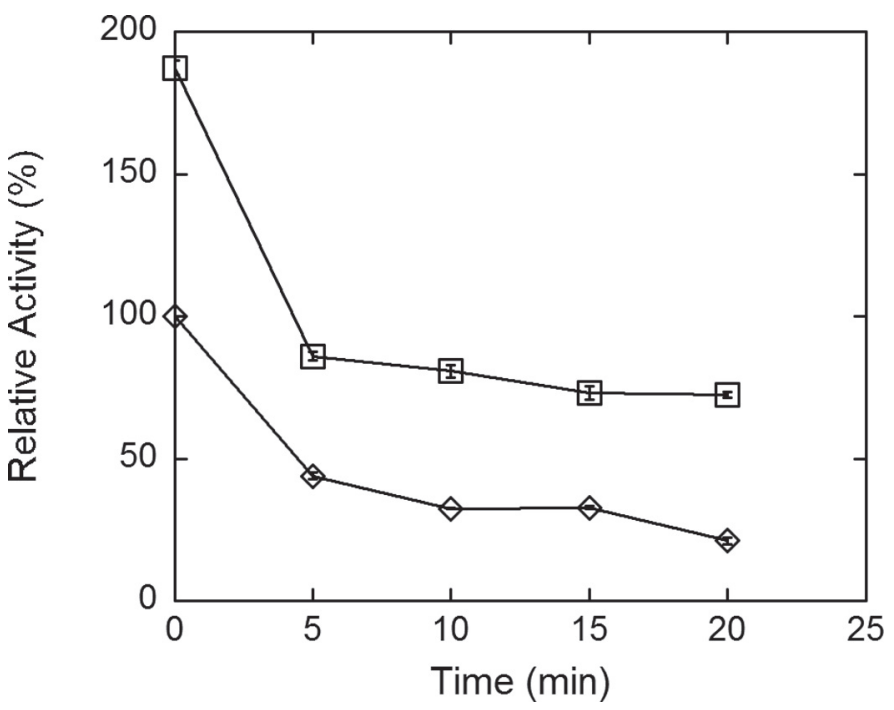

Figure 3. Effect of $\mathrm{Mn}^{2+}$ on enzyme thermostability. The protease was incubated at $80^{\circ} \mathrm{C}$ for $5,10,15$, and $20 \mathrm{~min}$ in the absence of manganese $(\diamond)$ and in the presence of $5 \mathrm{mM} \mathrm{Mn}^{2+}(\square)$. Activity was expressed as a percentage of the activity of a non-heat-treated enzyme. Error bar represents the mean of triplicate \pm SD. 

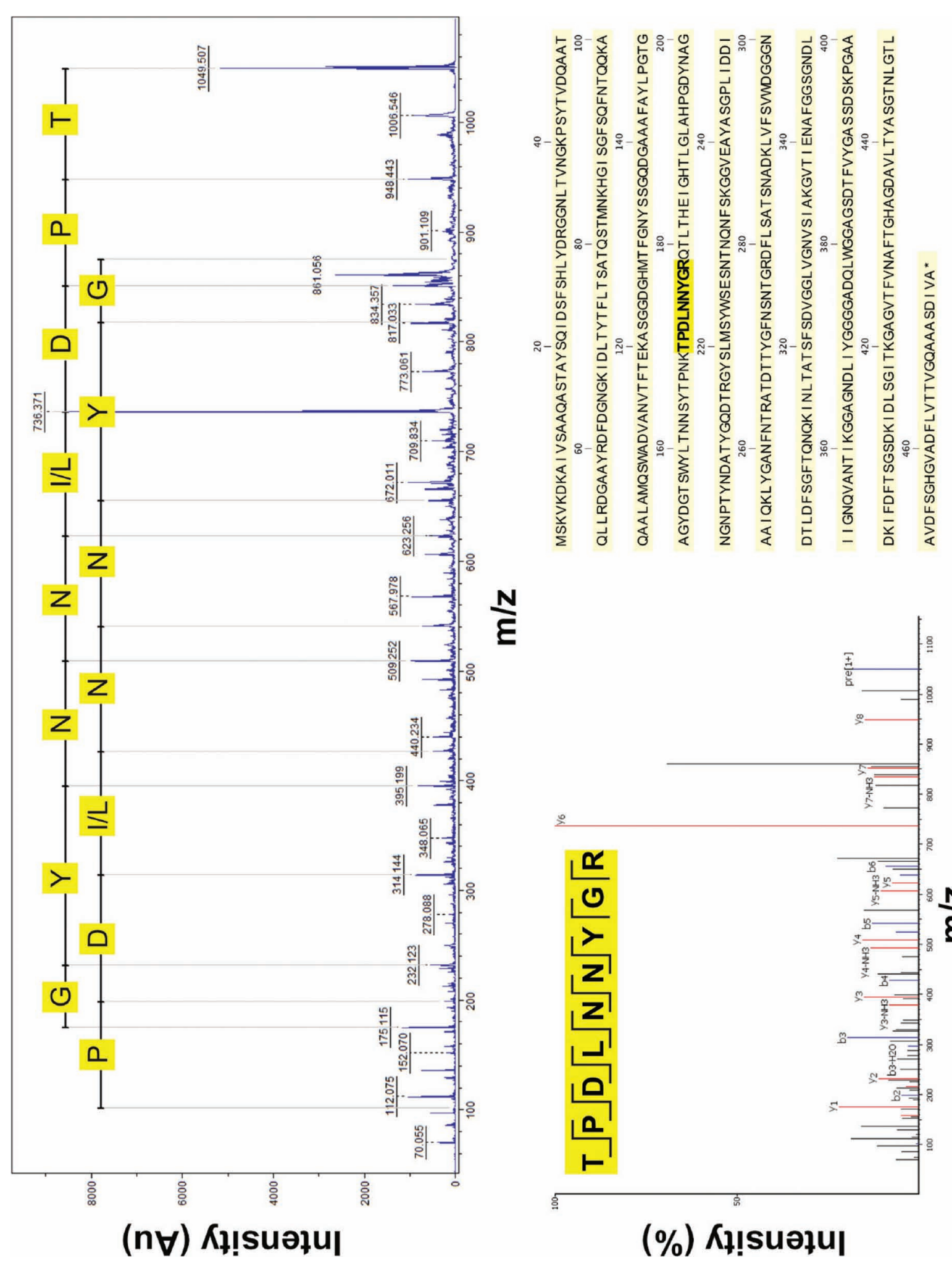

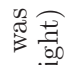

过

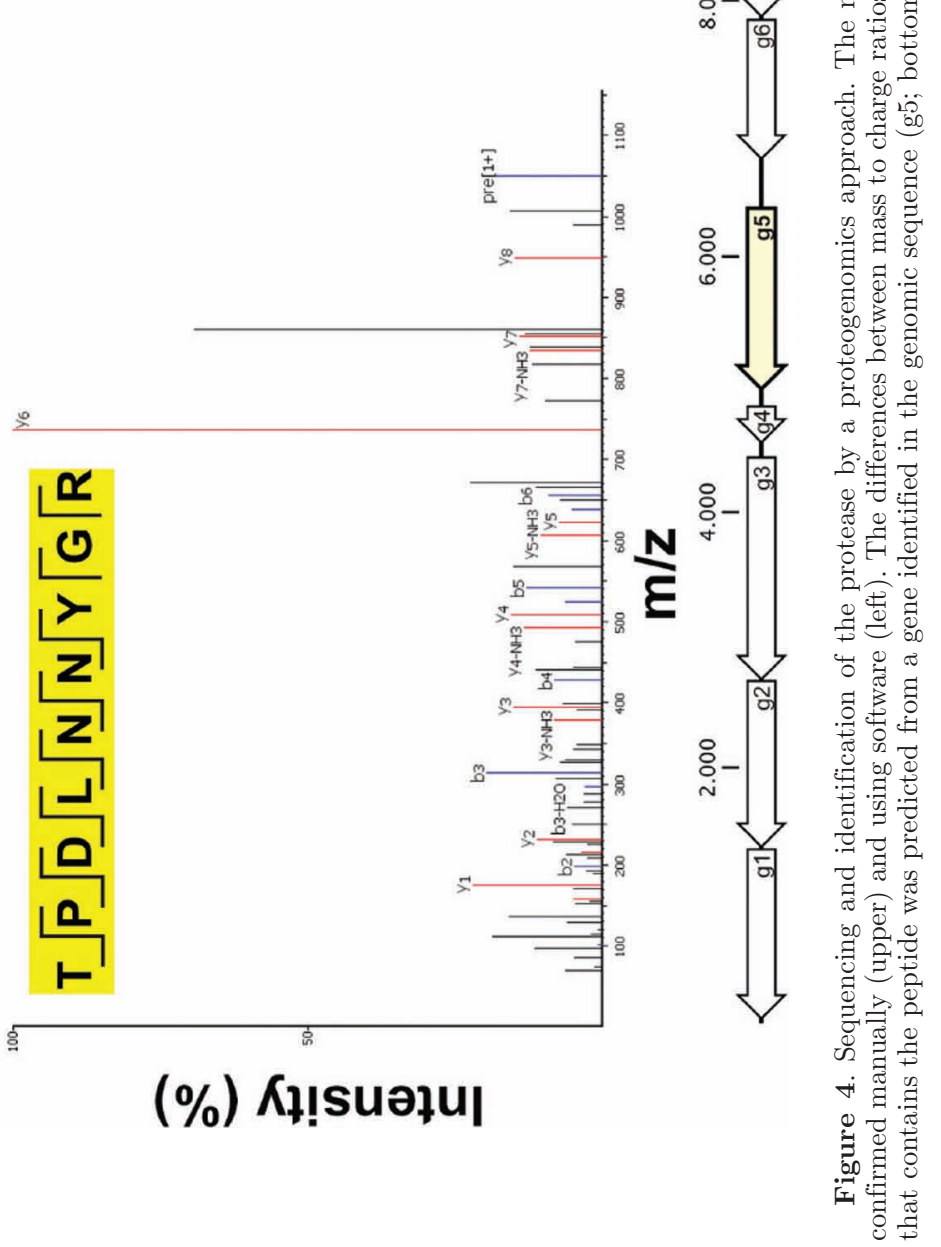


2011). The extracellular protease from P. fluorescens 07A presents activity in a wide range of conditions, as $\mathrm{pH} 5.0$ to 10.0 and temperatures from 4 to $60^{\circ} \mathrm{C}$, which include many of the conditions for storage of milk and dairy products. For example, Prato cheese is stored at approximately $12^{\circ} \mathrm{C}$ during ripening and has a $\mathrm{pH}$ near to 5.5 , conditions in which the enzyme presented over 26 and $54 \%$ activity, respectively. Similarly, pasteurized milk has a pH of 6.7 and is stored between 4 and $7^{\circ} \mathrm{C}$, conditions that also favor the hydrolytic activity. Considering UHT treatment, the milk can be stored for months at room temperature, which corresponds to the condition closer to the maximum protease activity and could explain why UHT milk is the product most affected by the technological problems caused by these proteases.

The high and almost constant activity presented by this protease in the range of $\mathrm{pH}$ over 7 was very particular. In the other hand, other proteases showed a continuous symmetrical reduction in their activities as the $\mathrm{pH}$ of the medium increased in relation to their $\mathrm{pH}$ of maximum activity (Huston et al., 2004; Mu et al., 2009; Zambare et al., 2011). The pH influences enzyme conformation and, consequently, the catalytic activity of their active site and their ability to recognize and bind the substrate. This occurs through changes in the ionization degree of AA residues, which directly interferes with hydrophobic interactions maintaining the enzyme structure. Thus, in this study, deprotonation generated by increasing the $\mathrm{pH}$ allowed the stabilization of the enzyme activity at $\mathrm{pH}$ above 8.0. It means that deprotonating does not cause a disruptive change in the enzyme structure, contributing to the behavior observed in this work for $\mathrm{pH}$ from 8.0 to 10.0.

No patterns are present for stimulation or inhibition of protease activity by ions. As the enzyme characterized in this study, other proteases produced by different bacteria have their activity stimulated in the presence of $\mathrm{Mn}^{2+}$ (Mu et al., 2009; Ibrahim et al., 2011; Salwan and Kasana, 2013), or inhibited by $\mathrm{Cu}^{2+}, \mathrm{Zn}^{2+}$, $\mathrm{Ni}^{2+}, \mathrm{Hg}^{2+}$, and $\mathrm{Fe}^{2+}$ (Sana et al., 2006; Divakar et al., 2010; Zambare et al., 2011). Stimulation of the enzyme activity by manganese ions suggests that it plays an important role in maintaining its active conformation (Kuddus and Ramteke, 2008), but how this stabilization occurs is still not known. However, this is again not a common pattern for Pseudomonas proteases, which usually require $\mathrm{Ca}^{2+}$ or $\mathrm{Zn}^{2+}$ as cofactors (Sørhaug and Stepaniak, 1997; Liao and McCallus, 1998; Jankiewicz et al., 2010).

Milk is a food rich in salts of phosphates, citrates, chlorides, sulfates, and carbonates of sodium, potassium, calcium, and magnesium (Fox and McSweeney,
1998). Thus, the activity of the protease from P. fluorescens $07 \mathrm{~A}$ might not be stimulated in milk because manganese salts are present only at low concentrations in this product $(30 \mu \mathrm{g} / \mathrm{L}$ or $0.55 \mu M)$ or even in concentrated milk products. An important finding is the fact that calcium, which is present in high concentrations in the milk $(1,200 \mathrm{mg} / \mathrm{L})$, is probably a cofactor for this enzyme, since it has a calcium-binding domain in its structure, like other proteases from psychrotrophic bacteria. This fact is reinforced by the fact that this protease activity was inhibited by EDTA and 1,10-phenanthroline, confirming that this enzyme is a metalloprotease, which is a group of enzymes that require metallic ions in the active site to maintain their structure and stability.

The presence of zinc inhibited the protease activity in proportion to its concentration, although the analysis of its sequence revealed the presence of a zinc-dependent metalloprotease, Serralysin-like subfamily, and a peptidase M10, a conserved protein domain family that suggest a zinc dependence for catalysis. An analysis of the sequence of a metalloprotease from a psychrophilic bacterium strain isolated from marine environment suggests that this enzyme needs $\mathrm{Zn}^{2+}$, although its characterization also has shown complete inhibition of its activity in the presence of this ion at 0.1, 1.0, and $10 \mathrm{~m} M$ (Huston et al., 2004). Furthermore, some $\mathrm{Zn}^{2+}$-dependent metalloproteases (for example, aminopeptidase, thermolysin) could be inhibited by an excess of this ion due to the formation of a zinc monhydroxide bridge (Larsen and Auld, 1989; Massaoud et al., 2011).

Activity reduction by DTT would suggest that this protease is stabilized by disulfide bonds. Similar findings were reported for other proteases from Pseudomonas (Gupta et al., 2005; Dufour et al., 2008; Tang et al., 2010). However, the absence of cysteine residues in the protease sequence remits to alternative mechanisms of reduction of enzymes activity by DTT. For example, DTT could act as a metal ion chelator, what could explain the inhibition of cofactor-dependent enzymes (Cornell and Crivaro, 1972; Yang et al., 1996; Paoletti et al., 1997). It was also hypothesized that DTT could inhibit enzyme activity by competing with its substrates, or even by steric hindrance via hydrogen interactions with amino acid residues in the catalytic domain (Alliegro, 2000). These findings demonstrate that the statement that enzymes inhibited by DTT would be stabilized by disulfide bonds, although true for many enzymes, must be confirmed by supplementary experiments.

Koka and Weimer (2000) affirmed that the competition for ions of these proteases with other milk proteins may be a factor regulating their activity. According 
to the authors, if the proteins present in milk have a higher binding affinity for metal ions than proteases, the hydrolysis of milk proteins by these proteases would be a strategy of these enzymes for obtaining ions in this product.

Heat treatments adopted by the dairy industry and the cooling conditions after processing may not be sufficient to completely inhibit the activity of proteolytic enzymes as the protease studied in this work (Figure 2 ). The thermostability pattern presented by this protease demonstrated the importance in determining the ideal combination of time and temperature for heat treatments in the industry, since a longer time for heat treatment $\left(65^{\circ} \mathrm{C}\right.$ for $\left.30 \mathrm{~min}\right)$ results in reduced enzymatic activity, although it may increase the destruction and inactivation of some milk constituents (Fellows, 2000). Alternatively, HTST treatment has been able to reduce activity to almost $30 \%$ within only $15 \mathrm{~s}$. More importantly, the protease was more stable when subjected to the treatment at $100^{\circ} \mathrm{C}$ for 5 min, compared with milder treatments.

Inactivation of some bacterial proteases deviates the first-order kinetics in certain temperature ranges (McKellar, 1989). In the literature, some reports describe proteases of psychrotrophic bacteria presenting this behavior, which is known as low-temperature inactivation. This could be mainly attributed to enzyme auto digestion or its aggregation with molecules of casein (Barach et al., 1978; McKellar, 1989; Stepaniak and Sørhaug, 1995).

Many other proteases produced by strains of $P$. fluorescens are also heat-resistant and retain activity even after UHT treatment. This residual activity can cause changes in the physicochemical properties of the casein micelles and lead to destabilization and gelation of UHT milk during storage (McPhee and Griffiths, 2011; Baglinière et al., 2013). Thus, adoption of appropriate practices for obtaining milk is necessary to minimize contamination of the raw material by psychrotrophic microorganisms.

The gene that encodes the extracellular protease of $P$. fluorescens $07 \mathrm{~A}$ was identified by a proteogenomics approach (Figure 4). A specific peptide sequenced by MALDI TOF/TOF allowed the identification of the gene that encodes the extracellular protease in the $P$. fluorescens $07 \mathrm{~A}$ genome and its complete AA sequence. The extracellular protease has $49.486 \mathrm{kDa}$ and its sequence is highly conserved among $P$. fluorescens strains (Supplemental Figure S1; http://dx.doi.org/10.3168/ jds.2016-11236), members of serralysin-like proteins. Serralysin are virulence factors in pathogenic bacteria and do not require signal sequences for transmembrane translocation. The proteases presenting similarity to the $P$. fluorescens 07A enzyme showed optimum activity in temperatures between 37 to $45^{\circ} \mathrm{C}$ and $\mathrm{pH} 7.0$ to 9.0 (Liao and McCallus, 1998; Anderson et al., 2004; Zhang et al., 2009). The characteristic of thermoresistance was also found for some of these proteases (Liao and McCallus, 1998).

The protease showing higher similarity with the protease sequenced in this study (C9WKP6) was isolated from the P. fluorescens strain TSS (Zhang et al., 2009), an aquaculture pathogen that can infect several fish species. Surprisingly, this protease has its activity stimulated by $10 \mathrm{mMCa}{ }^{2+}$ and $\mathrm{Zn}^{2+}$, even presenting only 2 AA substitutions in its sequence. One of these substitutions is located in the calcium-binding domain (343-385), where a serine residue in position 356 in the $P$. fluorescens $07 \mathrm{~A}$ sequence was substituted by an alanine residue. Miyajima et al. (1998) conducted an experiment with a Pseudomonas aeruginosa protease wherein they replaced an aspartate residue at position 356 by an alanine and verified that the protease activity was completely inhibited, showing the importance of this residue in binding this ion and therefore in regulating the catalytic activity of the enzyme.

\section{CONCLUSIONS}

This work shows the importance of the knowledge about the characteristics of proteolytic enzymes to control their activity in raw milk and hence reduce technological problems in dairy products. The protease has maximum activity at $37^{\circ} \mathrm{C}$ and $\mathrm{pH} 7.5$, which is compounded by its high residual activity after the most intense heat treatments administered. On the other hand, the significant reduction on protease activity under LTLT and HTST treatments highlights new perspectives to the treatment of milk to control technological problems caused by these enzymes.

\section{ACKNOWLEDGMENTS}

We are grateful to the Núcleo de Análise de Biomoléculas of the Universidade Federal de Viçosa for providing the facilities for running and conducting the experiments. The authors also acknowledge the financial support by the following Brazilian agencies: Fapemig, CAPES, and CNPq.

\section{REFERENCES}

Alliegro, M. C. 2000. Effects of dithiothreitol on protein activity unrelated to thiol-disulfide exchange: For consideration in the analysis of protein function with Cleland's reagent. Anal. Biochem. 282:102-106. http://dx.doi.org/10.1006/abio.2000.4557. 
Altuntas, E. G., K. Ayhan, S. Peker, B. Ayhan, and D. O. Demiralp. 2014. Purification and mass spectrometry based characterization of a pediocin produced by Pediococcus acidilactici 13. Mol. Biol. Rep. 41:6879-6885. http://dx.doi.org/10.1007/s11033-014-3573-z.

Anderson, L. M., V. O. Stockwell, and J. E. Loper. 2004. An extracellular protease of Pseudomonas fluorescens inactivates antibiotics of Pantoea agglomerans. Phytopathology 94:1228-1234.

Ayora, S., and F. Götz. 1994. Genetic and biochemical properties of an extracellular neutral metalloprotease from Staphylococcus hyicus ssp. hyicus. Mol. Gen. Genet. 242:421-430.

Baglinière, F., A. Matéos, G. Tanguy, J. Jardin, V. Briard-Bion, F. Rousseau, B. Robert, E. Beaucher, J. L. Gaillard, C. Amiel, G. Humbert, A. Dary, and F. Gaucheron. 2013. Proteolysis of ultra high temperature-treated casein micelles by AprX enzyme from Pseudomonas fluorescens $\mathrm{F}$ induces their destabilisation. Int. Dairy J. 31:55-61. http://dx.doi.org/10.1016/j.idairyj.2013.02.011.

Barach, J. T., D. M. Adams, and M. L. Speck. 1978. Mechanism of low temperature inactivation of a heat-resistant bacterial protease in milk. J. Dairy Sci. 61:523-528. http://dx.doi.org/10.3168/jds. S0022-0302(78)94405-3.

Bradford, M. M. 1976. A rapid and sensitive method for the quantitation of microgram quantities of protein utilizing the principle of protein-dye binding. Anal. Biochem. 72:248-254. http://dx.doi. org/10.1016/0003-2697(76)90527-3.

Cornell, N. W., and K. E. Crivaro. 1972. Stability constant for the zinc-dithiothreitol complex. Anal. Biochem. 47:203-208.

Datta, N., and H. C. Deeth. 2001. Age gelation of UHT milkA review. Inst. Chem. Eng. 79:197-210. http://dx.doi. org $/ 10.1205 / 096030801753252261$.

Decimo, M., S. Morandi, T. Silvetti, and M. Brasca. 2014. Characterization of gram-negative psychrotrophic bacteria isolated from Italian bulk tank milk. J. Food Sci. 79:M2081-M2090. http:// dx.doi.org/10.1111/1750-3841.12645.

Divakar, K., J. D. A. Priya, and P. Gautam. 2010. Purification and characterization of thermostable organic solvent-stable protease from Aeromonas veronii PG01. J. Mol. Catal., B Enzym. 66:311318

Dufour, D., M. Nicodème, C. Perrin, A. Driou, E. Brusseaux, G. Humbert, J.-L. Gaillard, and A. Dary. 2008. Molecular typing of industrial strains of Pseudomonas spp. isolated from milk and genetical and biochemical characterization of an extracellular protease produced by one of them. Int. J. Food Microbiol. 125:188-196. http:// dx.doi.org/10.1016/j.ijfoodmicro.2008.04.004.

Eller, M. R., P. M. P. Vidigal, R. L. Salgado, M. P. Alves, R. S. Dias, C. C. da Silva, A. F. de Carvalho, A. Kropinski, and S. O. De Paula. 2014. UFV-P2 as a member of the Luz24likevirus genus: A new overview on comparative functional genome analyses of the LUZ24-like phages. BMC Genomics 15: http://dx.doi. org/10.1186/1471-2164-15-7.

Ercolini, D., F. Russo, I. Ferrocino, and F. Villani. 2009. Molecular identification of mesophilic and psychrotrophic bacteria from raw cow's milk. Food Microbiol. 26:228-231. http://dx.doi. org/10.1016/j.fm.2008.09.005.

Feitosa, L., W. Gremski, S. S. Veiga, M. C. Q. Elias, E. Graner, O. C. Mangili, and R. R. Brentani. 1998. Detection and characterization of metalloproteinases with gelatinolytic, fibronectinolytic and fibrinogenolytic activities in Brown spider (Loxosceles intermedia) venom. Toxicon 36:1039-1051. http://dx.doi.org/10.1016/S00410101(97)00083-4.

Fellows, P. 2000. Food Processing Technology: Principles and Practice. 2nd ed. CRC Press, Boca Raton, FL.

Fox, P. F., and P. L. H. McSweeney. 1998. Dairy Chemistry and Biochemistry. 1st ed. Blackie Academic \& Professional, London, UK.

Gupta, A., I. Roy, S. K. Khare, and M. N. Gupta. 2005. Purification and characterization of a solvent stable protease from Pseudomonas aeruginosa PseA. J. Chromatogr. A 1069:155-161. http:// dx.doi.org/10.1016/j.chroma.2005.01.080.

Huston, A. L., B. Methe, and J. W. Deming. 2004. Purification, characterization, and sequencing of an extracellular cold-active aminopeptidase produced by marine psychrophile Colwellia psychr- erythraea Strain 34H. Appl. Environ. Microbiol. 70:3321-3328. http://dx.doi.org/10.1128/AEM.70.6.3321-3328.2004.

Ibrahim, K. S., J. Muniyandi, and S. K. Pandian. 2011. Purification and characterization of manganese-dependent alkaline serine protease from Bacillus pumilus TMS55. J. Microbiol. Biotechnol. 21:20-27.

Jankiewicz, U., U. Szawłowska, and M. Sobańska. 2010. Biochemical characterization of an alkaline metallopeptidase secreted by a Pseudomonas fluorescens isolated from soil. J. Basic Microbiol. 50:125-134. http://dx.doi.org/10.1002/jobm.200900054.

Koka, R., and B. C. Weimer. 2000. Isolation and characterization of a protease from Pseudomonas fluorescens RO98. J. Appl. Microbiol. 89:280-288.

Kuddus, M., and P. W. Ramteke. 2008. A cold-active extracellular metalloprotease from Curtobacterium luteum (MTCC 7529): Enzyme production and characterization. J. Gen. Appl. Microbiol. 54:385-392.

Laemmli, U. K. 1970. Cleavage of structural proteins during the assembly of the head of bacteriophage T4. Nature 227:680-685.

Larsen, K. S., and D. S. Auld. 1989. Carboxypeptidase A: mechanism of zinc inhibition. Biochemistry 28:9620-9625.

Liao, C.-H., and D. E. McCallus. 1998. Biochemical and genetic characterization of an extracellular protease from Pseudomonas fluorescens CY091. Appl. Environ. Microbiol. 64:914-921.

Martins, M. L., E. F. de Araújo, H. C. Mantovani, C. A. Moraes, and M. C. Vanetti. 2005. Detection of the apr gene in proteolytic psychrotrophic bacteria isolated from refrigerated raw milk. Int. J. Food Microbiol. 102:203-211. http://dx.doi.org/10.1016/j ijfoodmicro.2004.12.016.

Massaoud, M. K., J. Marokházi, and I. Venekei. 2011. Enzymatic characterization of a serralysin-like metalloprotease from the entomopathogen bacterium. Xenorhabdus. Biochim. Biophys. Acta 1814:1333-1339. http://dx.doi.org/10.1016/j.bbapap.2011.05.008.

McKellar, R. C. 1989. Enzymes of Psychrotrophs in Raw Food. CRC Press, Boca Raton, FL.

McPhee, J. D., and M. W. Griffiths. 2011. Psychrotrophic bacteria Pseudomonas spp. Pages 379-383 in Encyclopedia of Dairy Sciences. J. W. Fuquay, P. F. Fox, and P. L. H. McSweeney, ed. Academic Press, Cambridge, MA.

Miyajima, Y., Y. Hata, J. Fukushima, S. Kawamoto, K. Okuda, Y. Shibano, and K. Morihara. 1998. Long-range effect of mutation of calcium binding aspartates on the catalytic activity of alkaline protease from Pseudomonas aeruginosa. J. Biochem. 123:24-27.

Mu, Z., M. Du, and Y. Bai. 2009. Purification and properties of a heatstable enzyme of Pseudomonas fluorescens Rm12 from raw milk. Eur. Food Res. Technol. 228:725-734. http://dx.doi.org/10.1007/ s00217-008-0983-y.

Paoletti, P., P. Ascher, and J. Neyton. 1997. High-affinity zinc inhibition of NMDA NR1-NR2A receptors. J. Neurosci. 17:5711-5725.

Pinto, C. L. O. 2004. Bactérias psicrotróficas proteolíticas do leite cru refrigerado granelizado destinado à produção de leite UHT. Tese Universidade Federal de Viçosa, Viçosa, MG, Brazil.

Salwan, R., and R. C. Kasana. 2013. Purification and characterization of an extracellular low temperature-active and alkaline stable peptidase from psychrotrophic Acinetobacter sp. MN 12 MTCC (10786). Indian J. Microbiol. 53:63-69.

Sana, B., D. Ghosh, M. Saha, and J. Mukherjee. 2006. Purification and characterization of a salt, solvent, detergent and bleach tolerant protease from a new gamma-Proteobacterium isolated from the marine environment of the Sundarbans. Process Biochem. 41:208-215.

Sørhaug, T., and L. Stepaniak. 1997. Psychrotrophs and their enzymes in milk and dairy products: Quality aspects. Trends Food Sci. Technol. 8:35-41. http://dx.doi.org/10.1016/S0924-2244(97)01006-6.

Stepaniak, L., and T. Sørhaug. 1995. Thermal denaturation of bacterial enzymes in milk. Pages 349-363 in Heat Induced Changes in Milk. P. F. Fox, ed. International Dairy Federation, Brussels, Belgium.

Tang, X.-Y., B. Wu, H.-J. Ying, and B.-F. He. 2010. Biochemical properties and potential applications of a solvent-stable protease 
from the high-yield protease producer Pseudomonas aeruginosa PT121. Appl. Biochem. Biotechnol. 160:1017-1031. http://dx.doi. org/10.1007/s12010-009-8665-1.

von Neubeck, M., C. Baur, M. Krewinkel, M. Stoeckel, S. Scherer, and M. Wenning. 2015. Biodiversity of refrigerated raw milk microbiota and their enzymatic spoilage potential. Int. J. Food Microbiol. 211:57-65. http://dx.doi.org/10.1016/j.ijfoodmicro.2015.07.001.

Wiśniewski, J. R., A. Zougman, N. Nagaraj, and M. Mann. 2009 Universal sample preparation method for proteome analysis. Nat. Methods 6:359-362. http://dx.doi.org/10.1038/nmeth.1322.

Yang, Y., H. R. Wang, and H. M. Zhuo. 1996. Kinetics of inhibition of aminoacylase activity by dithiothreitol or 2-mercaptoethanol. Int. J. Pept. Protein Res. 48:532-538.
Zambare, V., S. Nilegaonkar, and P. Kanekar. 2011. A novel extracellular protease from Pseudomonas aeruginosa MCM B-327: Enzyme production and its partial characterization. N. Biotechnol. 28:173181. http://dx.doi.org/10.1016/j.nbt.2010.10.002.

Zhang, S., and J. Lv. 2014. Purification and properties of heat-stable extracellular protease from Pseudomonads fluorescens BJ-10. J. Food Sci. Technol. 51:1185-1190. http://dx.doi.org/10.1007/ s13197-012-0620-4.

Zhang, W., Y. Hu, H. Wang, and L. Sun. 2009. Identification and characterization of a virulence-associated protease from a pathogenic Pseudomonas fluorescens strain. Vet. Microbiol. 139:183-188. http://dx.doi.org/10.1016/j.vetmic.2009.04.026. 